\title{
POST-EXERCISE HYPOTENSION OF NORMOTENSIVE YOUNG MEN THROUGH TRACK RUNNING SESSIONS
}

\author{
HIPOTENSÃO PÓS-EXERCÍCIO DE HOMENS JOVENS E NORMOTENSOS EM SESSÕES \\ DE CORRIDA EM PISTA
}

Artigo Original

Original Article

Artículo Original

\author{
HIPOTENSIÓN POST-EJERCICIO DE HOMBRES EN SESIONES DE CARRERA EN PISTA \\ JÓVENES Y NORMOTENSOS
}

\begin{abstract}
Emerson Pardono 1
(Physical education instructor)

Manuella de Oliveira Fernandes ${ }^{1}$ (Physical education instructor)

Luan Morais Azevêdo'

(Physical education instructor)

Jeeser Alves de Almeida²

(Physical education instructor)

Marcio Rabelo Mota ${ }^{3}$

(Physical education instructor)

Herbert Gustavo Simões ${ }^{4}$

(Physical education instructor)

1. Universidade Federal de Sergipe (UFS), São Cristóvão, SE, Brasil.

2. Universidade Federal de Mato Grosso do Sul (UFMS), Campo Grande, MS, Brasil.

3. Centro Universitário de Brasília (UniCEUB), Brasília, DF, Brasil.

4. Universidade Católica de Brasília (UCB), Brasília, DF, Brasil.
\end{abstract}

\section{Correspondência:}

Universidade Federal de Sergipe, Departamento de Educação Física - Programa de Pós-Graduação em Educação Física. Cidade Universitária Prof. José Aloísio de Campos, Av. Marechal Rondon, s/n, Jardim Rosa Elze. 49100-000. São Cristóvão. SE, Brasil. pardono@ufs.br

\begin{abstract}
Introduction: After a single session of physical exercise the blood pressure is reduced (post-exercise hypotension, PHE) and it has been considered as a non-pharmacological mechanism to control the blood pressure. When the exercise is performed since youth it can prevent or avoid hypertension. However, it is important to consider studies with clear practical applications to optimize its reproducibility on a daily basis. Objective: Analyze the PEH of normotensive and physically active young men after two track running sessions (maximum and submaximal). Methods: Participated in this study 62 physically active young men ( $23.3 \pm 4.2$ years old; $75.5 \pm 9.8 \mathrm{~kg} ; 177.7 \pm 5.5 \mathrm{~cm} ; 12.0 \pm 4.6 \%$ body fatF; $52.4 \pm 4.0 \mathrm{~mL} . \mathrm{kg}^{-1} . \mathrm{min}^{-1}$ oxygen uptake), which performed a maximum laboratory exercise test for determination of maximal oxygen uptake $\left(\mathrm{VO}_{2 \max }\right.$ - aerobic power) and subsequently three randomly running sessions (maximum - T1600; submaximal - T20; control - CON), with 48h interval between themselves. Blood pressure (BP) was measured each $15 \mathrm{~min}$ during a 60 min period after sessions. Results: Both the maximum and the submaximal exercise lead to PEH. The post-exercise values of systolic blood pressure and diastolic blood pressure differed from resting value in session T20 ( $p<0.05)$. The same pattern occurred after T1600 ( $p<0.05$ ), evidenced from $30^{\text {th }}$ minute post-exercise. The CON did not result in PEH. The magnitude of decay for the mean $\mathrm{BP}$ at the $45^{\text {th }}$ after maximum exercise was higher than the other sessions $(p<0.05)$. Conclusion: We concluded that both maximum and submaximal exercises, performed on a track running condition, caused PEH in young normotensive and physically active men.
\end{abstract}

Keywords: exercise, arterial pressure, post-exercise hypotension.

\section{RESUMO}

Introdução: Após uma única sessão de exercício físico a pressão arterial é reduzida (hipotensão pós-exercício, HPE) e esta redução é considerada como um mecanismo não farmacológico para controlar a pressão arterial. Quando realizado desde a juventude, a atividade física pode prevenir ou evitar o surgimento da hipertensão arterial. Contudo, é importante considerar a realização de estudos com aplicações práticas claras para que seja otimizada a sua reprodutibilidade durante o dia-a-dia. Objetivo: Analisar a HPE em indivíduos jovens, normotensos e fisicamente ativos após duas sessões de corrida em pista (máxima e submáxima). Métodos: Participaram deste estudo 62 homens fisicamente ativos $\left(23,3 \pm 4,2\right.$ anos; $75,5 \pm 9,8 \mathrm{~kg} ; 177,7 \pm 5,5 \mathrm{~cm} ; 12,0 \pm 4,6 \%$ de gordura corporal; $52,4 \pm 4,0 \mathrm{~mL} . \mathrm{kg}^{-1}$. min $^{-1}$ consumo de oxigênio), os quais foram submetidos a um teste de exercício laboratorial para determinação do consumo máximo de oxigênio $\left(\mathrm{VO}_{2 \max }\right.$ - potência aeróbica) e subsequentemente três sessões aleatórias de corrida (máxima - T1600; submáxima - T20; controle - CON), com 48h de intervalo entre elas. A pressão arterial foi aferida a cada 15 min durante um período de 60 min após as sessões. Resultados: Ambos os exercícios (máximo e submáximo) proporcionaram HPE. Os valores pós-exercício da pressão arterial sistólica e diastólica diferiram dos valores de repouso na sessão T20 ( $p<0,05)$. O mesmo padrão ocorreu após o T1600 ( $p<0,05)$, evidenciado no 30. ${ }^{\circ}$ minuto pós-exercício. A sessão CON não resultou em HEP. A magnitude do decaimento para a pressão arterial média no $45 .^{\circ}$ minuto após o exercício máximo foi maior que nas demais sessões $(p<0,05)$. Conclusão: Concluímos que ambas as sessões de corrida em pista, máxima e submáxima, proporcionaram HPE em homens normotensos e fisicamente ativos.

Palavras-chave: exercício, pressão arterial, hipotensão pós-exercício.

\section{RESUMEN}

Introducción: Después de una única sesión de ejercicio físico la presión arterial es reducida (HPE) y esta reducción es considerada como un mecanismo no farmacológico para controlar la presión arterial y, cuando realizado desde la juventud, puede prevenir o evitar la aparición de la hipertensión arterial. Sin embargo, es importante considerar la realización de estudios con aplicaciones prácticas claras para optimizar su reproducibilidad durante el día a día. Objetivo: Analizar la HPE en individuos jóvenes, normotensos y físicamente activos después de dos sesiones de carrera en pista (máxima y submáxima). Métodos: Participaron en este estudio 62 hombres físicamente activos (23,3 $\pm 4,2$ años, $75,5 \pm 9,8 \mathrm{~kg}, 177,7 \pm 5,5 \mathrm{~cm}, 12,0 \pm 4,6 \%$ de grasa corporal, 52,4 $\left.44,0 \mathrm{~mL} \cdot \mathrm{kg}^{-1} . \mathrm{min}^{-1}\right)$, los que fueron sometidos a un test de ejercicios de laboratorio para determinación del control máximo de oxígeno. $\left(\mathrm{VO}_{2 \max }-\right.$ potencia aeróbica) 
y subsiguientemente tres sesiones randomizadas de HPE (máxima - T1600; submáxima - T20; control - CON), con 48 horas de intervalo entre ellas. La presión arterial fue medida a cada 15 minutos durante un período de 60 minutos después de las sesiones. Resultados: Ambos ejercicios (máximo e submáximo) proporcionaron HPE. Los valores post-ejercicio de la presión arterial sistólica y diastólica difirieron de los valores de reposo en la sesión T20 ( $p<0,05)$. El mismo patrón ocurrió después del T1600 ( $p<0,05)$, evidenciado en el $30^{\circ}$ minuto posterior al ejercicio. La sesión CON no resultó en HEP. La magnitud de decaimiento para la presión arterial promedio en el $45^{\circ}$ minuto posterior al ejercicio máximo fue mayor que en las demás sesiones $(p<0,05)$. Conclusión: Concluimos que ambas sesiones de carrera en pista, máxima y submáxima, proporcionaron HPE en hombres normotensos y físicamente activos.

Palabras clave: ejercicio, presión arterial, hipotensión post-ejercicio.

\section{INTRODUCTION}

The post-exercise hypotension (PEH) is characterized by a reduction of blood pressure (BP) to values below those observed at rest pre-exercise ${ }^{1}$ and have been studied for decades ${ }^{2}$. The PEH is evidenced after different stimuli, as seen in studies that used aerobic exercise ${ }^{1}$ or resistance exercise ${ }^{3,4}$, both in male ${ }^{5}$ and female 6 subjects and different. However, most of the researches is targeted to middle-aged and elderly people ${ }^{7-9}$ and who have some pathology, such as hypertension ${ }^{10,11}$, diabetes mellitus ${ }^{12,13}$ or chronic kidney disease ${ }^{14}$.

This tendency is associated with the fact that the PEH is currently considered a pivotal non pharmacological treatment of hypertension ${ }^{15,16}$, since the individuals with hypertension are at high risk of coronary heart disease, stroke and kidney diseases ${ }^{17}$. In this sense, investigations about this phenomenon in young ${ }^{18}$ and normotensive subjects ${ }^{19}$ are studied minority, due to lower clinical applicability when compared to studies conducted in middle-aged individuals, elderly and/or affected by pathologies.

Moreover, is necessary to develop studies in no laboratory conditions, such those performed by Holtzhausen and Noakes ${ }^{20}$ and Dujić et al. ${ }^{21}$ in normotensive and healthy persons, making it applied to the life style and relevant to investigate the influence of different exercise intensities and volumes on the PEH without the influence of aging and related pathologies.

Thus, the aim of this study was to analyze the PEH of normotensive and physically active young men from two running sessions (maximum and submaximal) under field conditions. Also, the magnitude of decay for the mean blood pressure was compared between sessions.

\section{MATERIALS AND METHODS}

This research was previously submitted and approved for the Ethics Committee and Research in humans of Catholic University of Brasília, Brasil, (CEP/UCB45/2008). Participated on this study sixty two physically active young men (table 1) after signing a term of consent. The volunteers had been practitioners of different sports for at least three months, three times per week, before the beginning of the study.

The volunteers initially performed a maximum laboratory exercise test for determination of maximal oxygen uptake $\left(\mathrm{VO}_{2 \max }\right.$ - aerobic power) and subsequently three more sessions randomly selected (two of than on a running track) with intervals of 48 hours between themselves, for analysis of PEH. The PEH analysis was conducted in a conditioned laboratory and all participants stayed seated while all data were collected. Perceived exertion (PE) was applied immediately after the tests.

Table 1. Biometric characteristics and aerobic power of volunteers $(n=62)$.

\begin{tabular}{c|c|c|c|c|c|c} 
& $\begin{array}{c}\text { Age } \\
(\text { years })\end{array}$ & $\begin{array}{c}\text { Weight } \\
(\mathbf{k g})\end{array}$ & $\begin{array}{c}\text { Height } \\
(\mathbf{c m})\end{array}$ & $\begin{array}{c}\mathrm{BMI} \\
(\mathbf{k g} / \mathbf{m} \mathbf{2})\end{array}$ & $\begin{array}{c}\text { Body Fat } \\
(\%)\end{array}$ & $\begin{array}{c}\mathbf{V O}_{2 \max } \\
\left(\mathbf{m L}^{\prime} \mathbf{k g}^{-1} \cdot \mathbf{m i n}^{-1}\right)\end{array}$ \\
\hline Mean & 23.3 & 75.5 & 177.7 & 23.9 & 12.0 & 52.4 \\
\hline$( \pm$ SD) & $( \pm 4.2)$ & $( \pm 9.8)$ & $( \pm 5.5)$ & $( \pm 2.5)$ & $( \pm 4.6)$ & $( \pm 4.0)$ \\
\hline
\end{tabular}

The incremental test started at a speed of $6.0 \mathrm{~km} \cdot \mathrm{h}^{-1}$ and inclination fixed at $1 \%$. An increasing of $0.75 \mathrm{~km}$.h.min ${ }^{-1}$ was applied ever minute until exhaustion. PE exceeding 17 on the Borg scale, respiratory exchange ratio (R) above 1.1, and/or heart rate values (HR) above $95 \%$ of maximum expected for their age were adopted as exhaustion criteria ${ }^{22}$. The gas analysis was obtained breath-by-breath using a gas analyzer Cortex Metalyzer 3B (Leipzig, Germany), and the highest values of oxygen uptake $\left(\mathrm{VO}_{2}\right)$ during the last 20 seconds of the test were considered for the determination of $\mathrm{VO}_{2 \text { max }}$ for each participant. The equipment was calibrated before each test according to manufacturer recommendations.

The BP was measured using an automatic, validated and calibrated, device (Microlife, model BP $3 A(1-1)^{23}$, and recorded values of systolic BP (SBP), diastolic BP (DBP) and mean BP (MBP). In pre-tests BP was measured each five minutes during 20 minutes and in post-tests each 15 minutes during 60 minutes. The mean of the measurements pre-test was performed to give the resting value (Rest) and the measurements each 15 minutes during 60 minutes after the sessions T1600, T20 and SC were defined as Post0, Post15, Post30, Post45 and Post60.

\section{Performance running Test on 1600 meters (maximum running)}

After the determination of Rest, the volunteers were moved to the running track, which performed a warm up (5 minutes).

Afterwards the procedures described above, participants ran a predetermined distance of 1.600 meters in the shortest time possible (T1600), on an athletics track ${ }^{22}$. Immediately after the test, the volunteers returned to the rest room to start the 60 minutes period, being in a sitting position, with constant measurement of BP (each 15min) for evaluation of maximum PEH.

\section{0-minute test (submaximal running)}

Following the same procedures of T1600, participants performed a submaximal running test on the same running track, however, in an exercise intensity equivalent to $75-80 \%$ of their heart rate reserve (HRres) and lasting 20 minutes (T20), similar the methodology employed by Mota et al., ${ }^{16}$ on a treadmill. As an aid to control the volunteers' exercise intensity, we used a frequency counter (Polar Sport Tester), so keeping the HR between the pre-calculated target zones.

Immediately after the test, the volunteers returned to the rest room to start the 60 minutes period, similar to the T1600 procedures, with constant measurement of BP (each $15 \mathrm{~min}$ ) for evaluation of submaximal PEH.

The control session (CON) was applied to verify the kinetics of BP after a specified period without exercise. Thus, the CON was conducted with a 20 minutes pre-exercise to determine the BP at rest (at rest room), followed by 20 minutes without exercise (simulating the total test time of the T20). Immediately after these 40 minutes, the volunteers stayed in the rest room, at the sitting position, with constant measurement of $\mathrm{BP}$, to evaluate the $\mathrm{BP}$ kinetics during 60 minutes at rest, without exercise. 


\section{Statistical Procedures}

Data were expressed as mean \pm standard deviation ( \pm SD). Exploratory analysis was performed using the Kolmogorov-Smirnov test to verify data followed a normal distribution and homogeneity of variance between groups was assessed by the Levene test. The analysis of variance (ANOVA) for repeated measures with multiple comparison between pairs by Bonferroni test was applied between the variables obtained from SBP and DBP during the post-exercise with the pre-exercise values within groups. Analysis of variance One-way ANOVA with Tukey post hoc test was used to compare between-groups from variations delta (post-exercise value less pre-exercise value) of MBP. The significance level was equal to or less than 0.05 . The statistical package SPSS version 17.0 was used.

\section{RESULTS}

In general, both the maximum (PSE $=17.5 \pm 2.0$ ) and the submaximal (PSE $=13.4 \pm 1.9$ ) exercise provided $\mathrm{PEH}$. The post-exercise values of SBP differ from resting value in T20 session $(p<0.05)$. The same reduction pattern occurred after T1600, however, the PEH was evidenced only from Post30 moment $(p<0.05)$. The CON did not result in $\mathrm{PEH}$ (table 2).

For DBP, both T20 and T1600 resulted in PEH (table 3, p<0.05) similarly to SBP, including not being observed PEH during the CON (table 3).

Comparisons between the delta of MBP from CON, T20 and T1600 for Post0 (0.1, 8.8 and 22.8, respectively) and Post45 (0.2, -5.4 and -7.3, respectively) showed differences between each other $(p<0.05)$. Further, the Post15 $(0.4,-3.2$ and -2.1 , respectively), Post30 $(0.2,-4.7$ and -5.4 , respectively) and Post60 (1.0, -4.8 and -6.2 , respectively) moments presented significant differences between SC and the other sessions (figure 1). These data showed that there was a greater magnitude of $\mathrm{PEH}$ at the 45 minutes of recovery after the exercise performed at maximum intensity.

Table 2. Mean ( $\pm \mathrm{SD}$ ) of systolic blood pressure (in $\mathrm{mmHg}$ ) during the three sessions for all volunteers.

\begin{tabular}{c|c|c|c|c|c|c}
\hline \multirow{2}{*}{} & \multirow{2}{*}{ Rest } & \multicolumn{5}{|c}{ Post-Exercise } \\
\cline { 3 - 7 } & & Post0 & Post15 & Post30 & Post45 & Post60 \\
\hline \multirow{2}{*}{ CON } & 120.3 & 119.6 & $\begin{array}{c}120.1 \\
( \pm 9.5)\end{array}$ & $\begin{array}{c}119.4 \\
( \pm 9.5)\end{array}$ & $\begin{array}{c}118.9 \\
( \pm 9.0)\end{array}$ & $\begin{array}{c}120.2 \\
( \pm 8.8)\end{array}$ \\
\hline \multirow{2}{*}{ T20 } & 120.4 & 137.7 & $115.4^{*}$ & $113.1^{*}$ & $112.4^{*}$ & $\begin{array}{c}112.6^{*} \\
( \pm 8.3)\end{array}$ \\
& $( \pm 8.4)$ & $( \pm 12.7)$ & $( \pm 9.1)$ & $( \pm 9.6)$ & $( \pm 8.6)$ & $( \pm 9.4)$ \\
\hline \multirow{2}{*}{ T1600 } & 122.1 & $166.3^{*}$ & 119.3 & $113.2^{* *}$ & $110.8^{* *}$ & $\begin{array}{c}112.2^{* *} \\
( \pm 9.0)\end{array}$ \\
& $( \pm 8.7)$ & $( \pm 19.6)$ & $( \pm 8.9)$ & $( \pm 8.8)$ & $( \pm 9.8)$ & $( \pm 9.9)$ \\
\hline
\end{tabular}

${ }^{*} p<0.05$ in relation to Rest and Post0 of $20 ;{ }^{* *} p<0.05$ in relation to Rest and Post 0 of $11600 ; " ~ p<0.05$ in relation to Rest and Post 15 of T1600 and Post0 of CON and T20.

Table 3. Mean $( \pm \mathrm{SD}$ ) diastolic blood pressure (in $\mathrm{mmHg}$ ) during the three sessions for all volunteers.

\begin{tabular}{c|c|c|c|c|c|c}
\hline \multirow{2}{*}{ Rest } & \multicolumn{5}{|c}{ Post-Exercise } \\
\cline { 3 - 7 } & & Post0 & Post15 & Post30 & Post45 & Post60 \\
\hline \multirow{2}{*}{ CON } & $\begin{array}{c}70.4 \\
( \pm 6.6)\end{array}$ & $\begin{array}{c}70.9 \\
( \pm 7.9)\end{array}$ & $\begin{array}{c}71.2 \\
( \pm 7.4)\end{array}$ & $\begin{array}{c}71.3 \\
( \pm 7.5)\end{array}$ & $\begin{array}{c}71.4 \\
( \pm 7.6)\end{array}$ & $\begin{array}{c}72.0 \\
( \pm 7.0)\end{array}$ \\
\hline \multirow{2}{*}{ T20 } & $\begin{array}{c}72.7 \\
( \pm 6.7)\end{array}$ & $\begin{array}{c}77.2 \\
( \pm 10.1)\end{array}$ & $\begin{array}{c}70.5^{*} \\
( \pm 8.0)\end{array}$ & $\begin{array}{c}69.3^{*} \\
( \pm 7.7)\end{array}$ & $\begin{array}{c}68.6^{*} \\
( \pm 7.5)\end{array}$ & $\begin{array}{c}69.4^{*} \\
( \pm 6.6)\end{array}$ \\
\hline \multirow{2}{*}{ T1600 } & 72.5 & $84.5^{*}$ & 70.7 & $\begin{array}{c}68.9^{* *} \\
( \pm 7.1)\end{array}$ & $\begin{array}{c}67.1^{* *} \\
( \pm 6.9)\end{array}$ & $\begin{array}{c}68.0^{* *} \\
( \pm 6.9)\end{array}$ \\
\hline
\end{tabular}

* $p<0.05$ in relation to Rest and Post 0 of $20 ; * * * 0.05$ in relation to Rest and Post 0 of $\mathrm{T} 1600 ; " \mathrm{p}<0.05$ in relation to Rest and Post15 of T1600 and Post0 of CON and T20.

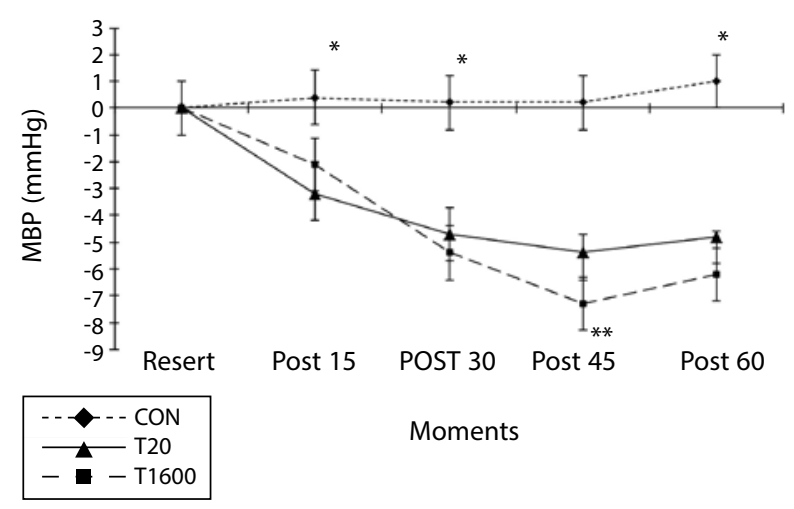

Figure 1. Delta of MBP (in $\mathrm{mmHg}$ ) during the three sessions. All values after T20 and T1600 differed from those corresponding to the same moments of CON ( $\left.{ }^{*} p<0.05\right)$, with a greater hypotensive effect at Post 45 from T1600 in relation to the corresponding moment of the other sessions $\left({ }^{* *} \mathrm{p}<0.05\right)$.

\section{DISCUSSION}

The aim of this research was to investigate the PEH in normotensive individuals through track running conditions and compare different running intensities. The most important finding was that both maximum and submaximal sessions track running resulted in $\mathrm{PEH}$ in physically active and healthy men, with higher magnitude of decay for the MBP after the maximum exercise intensity (tables 2 and 3 and figure 1).

Santana et al. ${ }^{24}$ observed that both maximum and submaximal exercises showed a protective effect on preventing the increase of BP during post-exercise recovery compared to control group in thirty hypertensive elderly women. These authors also found an increase in post-exercise salivary nitrite release that could be related to the endothelial oxide nitric release, probably because of the shear stress throughout the endothelium ${ }^{25}$ caused by the prior exercise.

These acute BP reductions after maximum and submaximal exercises may be helpful for a good endothelial function if the exercise is practiced with regularity and may even slow the deleterious physiological effects observed with aging on endothelial function ${ }^{26,27}$. Also, the $\mathrm{PEH}$ reduces the incidence of coronary heart disease, stroke and mortality in the general population ${ }^{28}$.

The reductions in post-exercise BP observed in our study corroborate the findings of other studies that investigated the submaximal $\mathrm{PEH}^{16,24,29}$, as well as those who analyzed the maximum $\mathrm{PEH}^{10,21,24,30-33}$ even though, in some cases, in different populations and age groups. According to Jones et al. ${ }^{34}$, the PEH appears to be clinically similar after exercise of high intensity and short duration when compared to the exercise of moderate intensity and longer duration.

Quinn ${ }^{35}$ and Forjaz et al. ${ }^{36}$ also reported that different exercise intensities resulted similar reductions in BP from normotensive individuals, as observed after resistance exercise in young ${ }^{3}$ and after submaximal and maximum exercise performed on a cycle ergometer and treadmill ${ }^{5}$.

In contrast, Pescatello et al. ${ }^{28}$ observed that the PEH obtained by performing an exercise at $60 \% \mathrm{VO}_{2 \max }$ was higher than that found at $40 \%$ of $\mathrm{VO}_{2 \max }$ for a period of five hours. Further, Forjaz et al. ${ }^{37}$ found reductions in $\mathrm{BP}$ of higher magnitude and duration after more intense exercises in normotensive, and Hagberg et al. ${ }^{38}$ and Lima et al..$^{29}$ also observed greater magnitude of $\mathrm{PEH}$ after more intense exercise in hypertensive and diabetic patients, respectively. In our study was also observed a higher magnitude of PEH at Post45 after the maximum exercise (figure 1), this reduction contributes to maintaining the health status of these individuals, who will take a long time to develop a cardiovascular disease ${ }^{39}$. 
Thus, the PEH kinetic appears to be dependent due to the stimulus, such as the volume-intensity interdependence of physical exercise as well as intensity. It's assumed that the last one, in some way, can influence the kinetics of $\mathrm{PEH}^{40}$. Still, as the BP, and probably the $\mathrm{PEH}$, seems to have a multifactorial origin, it may also be related to ethnic and genetic aspects ${ }^{22,41}$, thus its magnitude and duration may have different standards, so it's difficult to understand in different populations. What is known is that this multifactorial origin related to PEH results in both, changes in cardiac output and peripheral vascular resistance $\mathrm{e}^{1,42-45}$.

Regarding study limitations, it is noteworthy not control the total workload for the PEH of maximum and submaximal sessions could be adequately compared, which complicates the analysis to associate with PEH volume or intensity of exercise although we have conducted the reasoning for a possible relationship between the $\mathrm{PEH}$ and intensity and, most relevant, at applied conditions.

Although the results of BP after T1600 have been favorable in magnitude of $\mathrm{PEH}$ from the $45^{\text {th }}$ minute, one should be cautious when prescribing vigorous exercise for specific groups, such as diabetics 29 and older with a history of hypertension ${ }^{10}$, since the maximum effort shows a higher hemodynamic stress and cardiac overload. In this sense, it seems that for specific populations, who have risk factors to health, submaximal exercise (such as T20) may be more appropriate to obtain, safely, the PEH as suggested by Pescatello et al. ${ }^{46}$.

\section{REFERENCES}

1. MacDonald JR. Potential causes, mechanisms, and implications of post exercise hypotension. J Hum Hypertens. 2002;16(4):225-36

2. Halliwill JR. Mechanisms and clinical implications of post-exercise hypotension in humans. Exerc Sport Sci Rev. 2001;29(2):65-70

3. Lizardo JHF, Simões HG. Efeitos de Diferentes Sessões de Exercícios Resistidos sobre a Hipotensao Pós-Exercício. Rev Bras Fisioter. 2005;9(3):289-95.

4. Rezk CC, Marrache RC, TinucciT, Mion D Jr, Forjaz CL. Post-resistance exercise hypotension, hemodynamics, and heart rate variability: influence of exercise intensity. Eur J Appl Physiol. 2006;98(1):105-12. 5.

5. Lizardo J, Modesto L, Campbell C, Simões H. Post-exercise hypotension: comparison between different intensities of exercise on a treadmill and a cycle ergometer. Rev Bras Cineantropom Desempenho Hum. 2007;9(2):115-20.

6. Senitko AN, Charkoudian N, Halliwill JR. Influence of endurance exercise training status and gender on postexercise hypotension. J Appl Physiol (1985). 2002;92(6):2368-74

7. Moraes MR, Bacurau RF, Ramalho JD, Reis FC, Casarini DE, Chagas JR, et al. Increase in kinins on post-exercise hypotension in normotensive and hypertensive volunteers. Biol Chem. 2007;388(5):533-40.

8. Oneda B, Forjaz CL, Bernardo FR, Araújo TG, Gusmão JL, Labes E, et al. Low-dose estrogen therapy does not change postexercise hypotension, sympathetic nerve activity reduction, and vasodilation in healthy postmenopausal women. Am J Physiol Heart Circ Physiol. 2008;295(4):H1802-8.

9. Brito Ade F, de Oliveira CV Brasileiro-Santos Mdo S, Santos Ada C. Resistance exercise with different volumes: blood pressure response and forearm blood flow in the hypertensive elderly. Clin Interv Aging. 2014;9:2151-8.

10. Smith MW, Patterson N, Lautenberger JA, Truelove AL, MCDonald GJ, Waliszewska A, et al. A high-density admixture map for disease gene discovery in african americans. Am J Hum Genet. 2004;74(5):1001-13.

11. Mota MR, Oliveira RJ, Terra DF, Pardono E, Dutra MT, de Almeida JA, et al. Acute and chronic effects of resistance exercise on blood pressure in elderly women and the possible influence of ACE I/D polymorphism. Int J Gen Med. 2013;6:581-7.

12. Motta DF, Lima LC, Arsa G, Russo PS, Sales MM, Moreira SR, et al. Effect of type 2 diabetes on plasma kallikrein activity after physical exercise and its relationship to post-exercise hypotension. Diabetes Metab. 2010;36(5):363-8.

13. Simões GC, Moreira SR, Kushnick MR, Simões HG, Campbell CS. Postresistance exercise blood pressure reduction is influenced by exercise intensity in type-2 diabetic and nondiabetic individuals. J Strength Cond Res. 2010;24(5):1277-84

14. Headley SA, Germain MJ, Milch CM, Buchholz MP, Coughlin MA, Pescatello LS. Immediate blood pressure-lowering effects of aerobic exercise among patients with chronic kidney disease. Nephrology (Carlton). 2008;13(7):601-6.

15. Cunha GA da, Rios ACS, Moreno JR, Braga PL, Campbell CSG, Simões HG, et al. Hipotensão pós-exercício em hipertensos submetidos ao exercício aeróbio de intensidades variadas e exercício de intensidade constante. Rev Bras Med Esporte. 2006;12(6):313-7.

16. Mota MR, Pardono E, Lima LC, Arsa G, Bottaro M, Campbell CS, Simões HG. Effects of treadmill running and resistance exercises on lowering blood pressure during the daily work of hypertensive subjects. J Strength Cond Res. 2009;23(8):2331-8.

17. Messerli FH, Williams B, Ritz E. Essential hypertension. Lancet. 2007;370(9587):591-603.

18. Halliwill JR, Minson CT, Joyner MJ. Effect of systemic nitric oxide synthase inhibition on postexercise hypotension in humans. J Appl Physiol (1985). 2000;89(5):1830-6.

19. Williamson JW, Querry R, McColl R, Mathews D. Are decreases in insular regional cerebral blood flow sustained during postexercise hypotension? Med Sci Sports Exerc. 2009;41(3):574-80.

20. Holtzhausen LM, Noakes TD. The prevalence and significance of post-exercise (postural) hypotension in ultramarathon runners. Med Sci Sports Exerc. 1995;27(12):1595-601.

21. Dujić Z, Ivancev V, Valic Z, Bakovic D, Marinović-Terzić I, Eterović D, et al. Postexercise hypotension in moderately trained athletes after maximal exercise. Med Sci Sports Exerc. 2006;38(2):318-22.

22. Almeida JA, Boullosa DA, Pardono E, Lima RM, Morais PK, Denadai BS, et al. The influence of ACE genotype on cardiovascular fitness of moderately active young men. Arq Bras Cardiol. 2012;98(4):315-20.

23. Topouchian JA, El Assaad MA, Orobinskaia LV, El Feghali RN, Asmar RG. Validation of two devices for self-
Anyway, do not rule out the possibility of prescribing high intensity for risk populations, particularly if they are trained, as for young and normotensive people. High intensity with low volume seems interesting to result $\mathrm{PEH}$ and maintain adequate BP values under field conditions.

\section{CONCLUSION}

We conclude that both maximum and submaximal exercises performed in track running conditions provided PEH in young normotensive and physically active men. In addition, the higher exercise intensity promoted higher decay of MBP at the 45th minute from recovery period.

It is suggested that further studies, at different populations and/ or at different intensities and volumes of exercise, be performed in no-laboratory conditions, as well as investigate the hypotensive effect during daily tasks. In this sense, the researchers will become more applicable and closer to day-to-day reality.

\section{ACKNOWLEDGEMENT}

We would like to thank Coordination for the Improvement of Higher Education Personnel (CAPES) for the financial support.

All authors have declared there is not any potential conflict of interests concerning this article.

-measurement of brachial blood pressure according to the International Protocol of the European Society of Hypertension: the SEINEX SE-9400 and the Microlife BP 3AC1-1. Blood Press Monit. 2005;10(6):325-31.

24. Santana HA, Moreira SR, Neto WB, Silva CB, Sales MM, Oliveira VN, et al. The higher exercise intensity and the presence of allele I of ACE gene elicit a higher post-exercise blood pressure reduction and nitric oxide release in elderly women: an experimental study. BMC Cardiovasc Disord. 2011;11:71.

25. Lüscher TF, Corti R. Flow: the signal of life. Circ Res. 2004;95(8):749-51.

26. Taddei S, Virdis A, Mattei P, Ghiadoni L, Fasolo CB, Sudano I, et al. Hypertension causes premature aging of endothelial function in humans. Hypertension. 1997;29(3):736-43.

27. Barac A, Panza JA. Mechanisms of decreased vascular function with aging. Hypertension. 2009;53(6):900-2.

28. Pescatello LS, Guidry MA, Blanchard BE, Kerr A, Taylor AL, Johnson AN, et al. Exercise intensity alters postexercise hypotension. J Hypertens. 2004;22(10):1881-8.

29. Lima LC, Assis GV, HiyaneW, Almeida WS, Arsa G, Baldissera V, et al. Hypotensive effects of exercise performed around anaerobic threshold in type 2 diabetic patients. Diabetes Res Clin Pract. 2008;81(2):216-22

30. Piepoli M, Lombardi F, Bigoli M, Achilli G, Maj L. Hypotension following maximum physical exercise. Evaluation of hemodynamic and humoral mechanisms. Minerva Cardioangiol. 1993;41(10):445-9.

31. Notarius CF, Morris BL, Floras JS. Caffeine attenuates early post-exercise hypotension in middle-aged subjects. Am J Hypertens. 2006;19(2):184-8.

32. Cunha G. Papel do sistema calicreína-cininas sobre os efeitos hipotensores e hipoglicemiantes do exercício em diabético tipo 2 [tese]. Brasília, DF: Universidade Católica de Brasília; 2008.

33. Rossow L, Yan H, Fahs CA, Ranadive SM, Agiovlasitis S, Wilund KR, et al. Postexercise hypotension in an endurance-trained population of men and women following high-intensity interval and steady-state cycling. Am J Hypertens. 2010;23(4):358-67.

34. Jones $\mathrm{H}$, George K, Edwards B, Atkinson G. Is the magnitude of acute post-exercise hypotension mediated by exercise intensity or total work done? Eur J Appl Physiol. 2007;102(1):33-40.

35. Quinn TJ. Twenty-four hour, ambulatory blood pressure responses following acute exercise: impact of exercise intensity. J Hum Hypertens. 2000;14(9):547-53.

36. Forjaz CL, Matsudaira Y, Rodrigues FB, Nunes N, Negrão CE. Post-exercise changes in blood pressure, heart rate and rate pressure product at different exercise intensities in normotensive humans. Braz $\mathrm{J}$ Med Biol Res. 1998;31(10):1247-55.

37. Forjaz CL, Cardoso CG Jr, Rezk CC, Santaella DF, Tinucci T. Postexercise hypotension and hemodynamics: the role of exercise intensity. J Sports Med Phys Fitness. 2004;44(1):54-62.

38. Hagberg JM, Montain SJ, Martin WH 3rd. Blood pressure and hemodynamic responses after exercise in older hypertensives. J Appl Physiol (1985). 1987;63(1):270-6.

39. Whelton PK, He J, Appel LJ, Cutler JA, Havas S, Kotchen TA, et al. Primary prevention of hypertension: clinical and public health advisory from The National High Blood Pressure Education Program. JAMA. 2002;288(15):1882-8.

40. Casonatto J, Polito MD. Hipotensão pós-exercício aeróbio: uma revisão sistemática. Rev Bras Med Esporte. 2009;15(2):151-7.

41. Pardono E, Almeida MB de, Bastos A de A, Simões HG. Post-exercise hypotension: possible relationship with ethnic and genetic factors. Rev Bras Cineantropom Desempenho Hum. 2012;14(3):353-61.

42. Halliwill JR, Taylor JA, Eckberg DL. Impaired sympathetic vascular regulation in humans after acute dynamic exercise. J Physiol. 1996;495( Pt 1):279-88.

43. Guyton CA, Hall EJ. Fisiologia humana e mecanismos das doenças. 6a. ed. Rio de Janeior, RJ: Guanabara; 1998.

44. Forjaz CL, Tinucci T, Ortega KC, Santaella DF, Mion D Jr, Negrão CE. Factors affecting post-exercise hypotension in normotensive and hypertensive humans Blood Press Monit. 2000;5(5-6):255-62.

45. Laterza MC, Rondon MUPB, Negrão CE. Efeito anti-hipertensivo do exercício. Rev Bras Hipertens. 2007;14(2):104-11.

46. Pescatello LS, Turner D, Rodriguez N, Blanchard BE, Tsongalis GJ, Maresh CM, et al. Dietary calcium intake and renin angiotensin system polymorphisms alter the blood pressure response to aerobic exercise: a randomized control design. Nutr Metab (Lond). 2007;4:1. 